\title{
Are Obesity, Diabetes, and Hypertension Risk Factors for Cervical Polyps?
}

\author{
Diyabet, Hipertansiyon ve Obezite \\ Servikal Polipler İçin Risk Faktörü müdür?
}

\section{Mustafa Gazi UÇAR, ${ }^{a}$ \\ Rahime Merve UCAR, ${ }^{b}$ \\ Tolgay Tuyan ILHAN, ${ }^{a}$ \\ Tansel ÇAKIR, ${ }^{a}$ \\ Zekiye SOYKAN SERT, \\ Çetin ÇELIKa}

${ }^{a}$ Department of Obstetrics and Gynecology, Selçuk University Faculty of Medicine, bHekim Hacı Paşa Family Health Center No 34 ,

Konya

Geliș Tarihi/Received: 13.10 .2016 Kabul Tarihi/Accepted: 07.12.2016

Yazışma Adresi/Correspondence: Mustafa Gazi UÇAR

Selçuk University Faculty of Medicine, Department of Obstetrics and Gynecology, Konya,

TÜRKIYE/TURKEY

mustafa_gazi_ucar @ hotmail.com

\begin{abstract}
Objective: To investigate whether diabetes, hypertension, and obesity can be considered risk factors for cervical polyps. Material and Methods: The hospital-based case-control study was carried out. We retrospectively reviewed the records of 307 consecutive patients with cervical polyps. A control group consisting of 3 women per case-matched by the same age, same parity, same menopausal status and the same presenting symptoms. These groups were compared with respect of diabetes, hypertension and obesity prevalence. Results: The study included a total of 212 patients eligible for analysis in cervical polyp group, and a matched control group consisting of 636 women without cervical polyp. Women with cervical polyp had higher body mass index than the controls, but the difference was not statistically significant $(\mathrm{p}=0.72)$. The prevalence of obesity was significantly higher in the cervical polyp group than the controls $(\mathrm{p}=0.016)$. A statistically significant correlation was found between obesity and cervical polyps (OR: 1.351, CI: 1.0621,718). There was no significant difference between the groups with respect to the prevalence of diabetes $(\mathrm{p}=0.795)$ and hypertension $(\mathrm{p}=0.703)$. Conclusion: Obesity appears to be a risk factor for cervical polyps. Obese women should receive special attention for potential coexistence of cervical polyps as part of their gynecological evaluation. This study supports the importance of weight management for the preventive plan of cervical polyps.
\end{abstract}

Key Words: Cervix uteri; polyps; diabetes mellitus; hypertension; obesity

ÖZET Amaç: Diyabet, hipertansiyon ve obezitenin servikal polipler için risk faktörü olup olmadığını araştırmaktır. Gereç ve Yöntemler: Hastane tabanlı vaka-kontrol çalışması oluşturuldu. 307 ardıșık servikal polip hastasının kayıtları retrospektif olarak değerlendirildi. Her servikal polip hastası için, aynı yaş, aynı parite, aynı menopozal durumda ve aynı başvuru şikayeti ile gelen 3 kontrol hastası belirlendi. Gruplar hipertansiyon, diyabet ve obezite prevalansı açısından karşılaştırıldı. Bulgular: Çalışma kriterlerine uygun servikal polibi olan 212 hasta vaka grubuna ve servikal polibi olmayan eşleştirilmiş 636 hasta kontrol grubuna dahil edildi. Servikal polip hastalarının beden kitle indeksi, kontrol grubundan daha fazlaydı, ancak bu fark istatistiksel anlamlı degildi $(p=0,72)$. Obezite prevalansı servikal polip grubunda, kontrol grubundan istatistiksel olarak anlamlı düzeyde yüksek bulundu $(\mathrm{p}=0,016)$. Obezite ve servikal polipler arasında istatistiksel anlamlı düzeyde korelasyon saptandı (OR: 1,351, GA: 1,062-1,718). iki grup arasında hipertansiyon $(\mathrm{p}=0,703)$ ve diyabet $(\mathrm{p}=0,795)$ prevalansı değerlendirildiğinde istatistiksel olarak anlamlı fark tespit edilmedi. Sonuç: Obezite servikal polipler için risk faktörü olarak görünmektedir. Obez hastalara muhtemel servikal polip birlikteliği nedeniyle jinekolojik muayene sırasında özellikle dikkat edilmelidir. Çalışma servikal poliplerin koruyucu tedavisinde kilo kontrolünün önemini desteklemektedir.

Anahtar Kelimeler: Serviks uteri; polipler; diabetes mellitus; hipertansiyon; obezite

Turkiye Klinikleri J Gynecol Obst 2016;26(4):226-31

ervical polyps are common benign neoplasms of the cervix in adult women. ${ }^{1}$ They are believed to develop as a result of focal hyperplasia. They usually develop in multiparous women during the fifth 
decade of life. ${ }^{2}$ Majority of cervical polyps are incidental findings due to their small size and asymptomatic nature. Symptomatic cervical polyps may cause intermenstrual bleeding, postcoital bleeding, heavy menses, postmenopausal bleeding and vaginal discharge..$^{3-5}$ They tend to be solitary, measure up to several centimetres in diameter, and are attached to the cervix by a stalk of varying length . Although cervical polyps are frequently observed, the etiology is not yet fully clear. ${ }^{1-3,5}$ To date, there are limited published studies about cervical polyps as well as the research for risk factors that contribute to the etiology. Chronic inflammation (chronic cervicitis, foreign bodies), localised collection/congestion of cervical vasculature, an abnormal local response to hormone stimulation, and other theories have been proposed to explain their pathogenesis. ${ }^{1,3}$ It was reported that diabetes mellitus (DM), hypertension (HT), and obesity may be risk factors for endometrial polyps even if it is not yet studied whether these conditions primarily influence the development of cervical polyps..$^{6-8}$ To address this area, this study focused on whether diabetes, hypertension, and obesity can be considered risk factors for cervical polyps.

\section{MATERIAL AND METHODS}

\section{STUDY DESIGN, SETTING AND PATIENTS}

The hospital-based case-control study was carried out retrospectively. A total of 307 consecutive women underwent polypectomy (confirmed with histopathological results) during a routine outpatient examination between January 2010 and December 2014. Data of the patients were obtained from hospital records. To confirm information, the telephone interview was conducted and all of the patients were subjected to the phone questionnaire. Patients whose height and weight measurements were inaccessible while the first examination, patients not reached by telephone, pregnant women, patients with polycystic ovary syndrome, patients using intrauterine device, those receiving hormone replacement therapy (HRT), birth control pills and Tamoxiphene (Nolvadex, AstraZeneca, UK) were excluded. A total of 212 patients met the criteria and were included in cervical polyp group.
The diagnosis of cervical polyps was made histologically after polypectomy. It is easy to perform in office setting by grasping the base of the lesion with looped forceps and twisting gently until it comes off. Sometimes a silver nitrate stick is used for hemostasis of bleeding small vessels and to reduce the likelihood of recurrence.

A control group consisting of 3 women per case matched by the same age, same parity, same menopausal status and presenting the same symptoms in outpatient clinic was formed. The most common presenting symptoms were abnormal vaginal bleeding, vaginal discharge and pelvic pain. A total of 636 patients were included in the control group. These groups were compared with respect of HT, DM and obesity prevalence and Body Mass Index (BMI) measurement.

The research project has been approved by the Ethics Committee of the institution. Written informed consent was obtained from the patients.

\section{DATA ELEMENTS}

DM diagnosis was assigned to the following diabetes registration criteria: documentation of an inpatient or outpatient type 1 or $2 \mathrm{DM}$ diagnosis, having fasting plasma glucose greater than 126 $\mathrm{mg} / \mathrm{dL}$, or having DM medication. The patients with two blood pressure measurements greater than 140/90 $\mathrm{mm} \mathrm{Hg}$ and anti-hypertensive drug use were accepted as HT. BMI was defined as weight in kilograms divided by the square of the height in metres $\left(\mathrm{kg} / \mathrm{m}^{2}\right)$ and stratified as normal $\left(<25 \mathrm{~kg} / \mathrm{m}^{2}\right)$, overweight $\left(25-29.9 \mathrm{~kg} / \mathrm{m}^{2}\right)$, and obese $\left(\geq 30 \mathrm{~kg} / \mathrm{m}^{2}\right)$.

\section{STATISTICAL ANALYSIS}

The data were analysed using SPSS for Windows software (ver. 15.0; SPSS Inc., Chicago, IL, USA). Descriptive statistics were expressed as mean \pm SD (range) for continuous variables and frequency (percentage) for categorical variables. Continuous variables are compared using t-tests; categorical variables are compared using chi-squared tests. Binary logistic regression was used to compute the odds ratio for cervical polyps in patients with obesity, diabetes, and hypertension, respectively. P- 
values $<0.05$ were considered statistically significant.

\section{RESULTS}

The study included a total of 212 patients eligible for analysis in the cervical polyp group and the matched control groups consisting of 636 women without cervical polyp. The mean BMI was $28.77 \pm$ $4.44 \mathrm{~kg} / \mathrm{m}^{2}$ (range 19.20-40.80) in cervical group and $28.16 \pm 4.19 \mathrm{~kg} / \mathrm{m}^{2}$ (range 20.50-43.20) in the controls. Women with cervical polyp had higher $\mathrm{BMI}$ than the controls, but the difference was not statistically significant $(\mathrm{p}=0.720)$. The obesity prevalence in cervical group and control group was $32.1 \%$ and $23.7 \%$ respectively. The prevalence of obesity was significantly higher in the cervical polyp group than the controls $(\mathrm{p}=0.016)$. Furthermore, obese patients have statistically significant higher risk to have cervical polyp (OR: 1.351, CI: 1.062-1.718). There was no significant difference between groups with respect to prevalence of diabetes $(\mathrm{p}=0.795)$ and hypertension $(\mathrm{p}=0.703)$. Results of statistical analysis are detailed in Table 1 . The mean age in cervical polyp group was $48.61 \pm 6.48$ years ranged in age from 36 to 70 years. The highest percentage $(77.83 \%)$ of patients with cervical polyps was observed in the 40- to 55-year-old age group. Age distributions of patients with cervical polyps were shown graphically in Figure 1.

TABLE 1: The prevalence of obesity, diabetes, and hypertension in cases and controls.

\begin{tabular}{|lcccc|}
\hline & Polyp & Non-polyp & OR & \\
Variables & $(\mathbf{n}=212)$ & $(\mathbf{n}=636)$ & $(95 \% \mathrm{Cl})$ & $\mathbf{p}$ \\
Hypertension & 49 & 139 & 1.058 & 0.703 \\
& $(23.1 \%)$ & $(21.9 \%)$ & $(0.794-1.408)$ & \\
Diabetes & 23 & 65 & 1.062 & 0.795 \\
& $(10.8 \%)$ & $(10.2 \%)$ & $(0.677-1.664)$ & \\
Obesity $(\mathrm{BMI} \geq 30)$ & 68 & 151 & 1.351 & $0.016^{*}$ \\
& $(32.1 \%)$ & $(23.7 \%)$ & $(1.062-1.718)^{\star}$ & \\
BMI $\left(\mathrm{kg} / \mathrm{m}^{2}\right)$ & $28.7 \pm 4.4$ & $28.1 \pm 4.1$ & & 0.720 \\
\hline
\end{tabular}

*Statistically significant.

OR: Odds Ratio, Cl: Confidence Interval; BMI: Body Mass Index, n: indicates the number of patients.

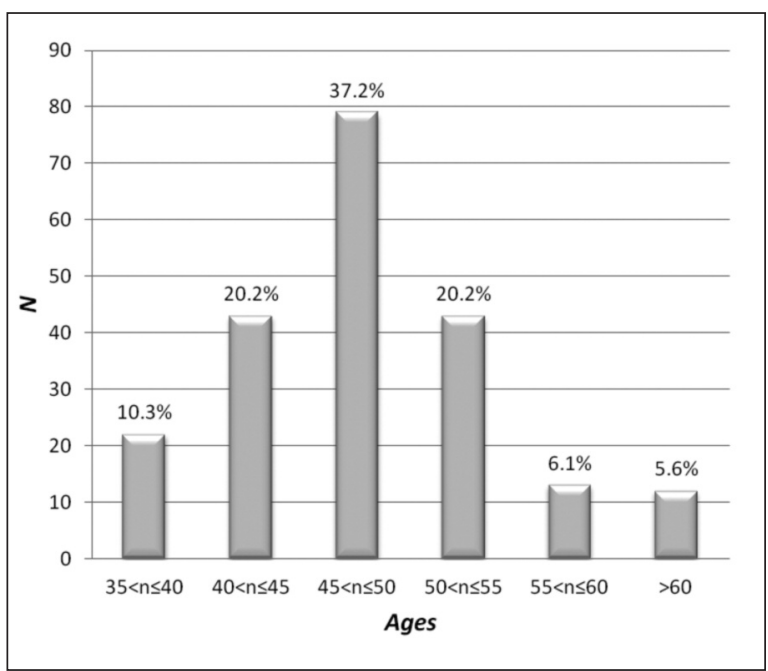

FIGURE 1: Age distributions of patients with cervical polyps.

\section{DISCUSSION}

The pathogenesis, risk factors, and etiology of cervical polyps remain unclear. ${ }^{1-3,5}$ Most of the studies in the literature focusing on etiological factors are related with endometrial polyps. Hormonal factors, obesity, late menopause, hormone replacement therapy, polycystic ovary syndrome and Tamoxiphene (Nolvadex, AstraZeneca, UK) use are thought to play an important role in endometrial polyps. ${ }^{6,7} \mathrm{~A}$ higher prevalence of endometrial polyps was found among women with a cervical polyp (26.9\%). ${ }^{9}$ Additionally, a relationship between cervical polyps with endometrial hyperplasia and endometrial polyps have been observed. ${ }^{9-12}$ Therefore, cervical polyps may share the same risk factors. To our knowledge, this is the first reported study comparing DM, HT, and obesity prevalence between patients with and without cervical polyps.

It is well known that rising obesity rates around the world have a profound impact on female reproductive health. ${ }^{13}$ Increased leptin levels and decreased growth hormone (GH), decreased sex hormone binding globulin, and decreased insulin like growth factor binding proteins (IGFBPs) are observed in obese women. ${ }^{13}$ Alterations in neuroregulation of the hypothalamic-pituitarygonadal axis and alterations in gonadotropin secretion have also been described in obesity. ${ }^{13}$ In this study, obesity was found to be a risk factor for the 
development of cervical polyps. No significant relationship between HT, DM and cervical polyps was determined.

Since both benign and malignant uterine diseases are related to estrogen action, the hormonally regulated local IGF-1 system may play an important role in the pathophysiology of uterine diseases. ${ }^{14}$ The molecular and experimental findings demonstrate that DM, obesity and unopposed estrogen leads to abnormal increase of certain growth factors, such as IGF-1 fibroblastic GF, transforming GF-a, epithelial GF, IGF-1, and GF receptors within the endometrium. ${ }^{14-16} \mathrm{DM}$, HT and obesity are also pathological conditions that may probably trigger the abnormal rise of many growth factors in serum and endometrial tissue. ${ }^{8-17}$ In this study, the obesity prevalence in cervical group and control group was $32(1 \%)$, and $23(7 \%)$, respectively. Obese women have also a higher risk of insulin resistance, hyperinsulinemia and hyperandrogenemia. Increased peripheral aromatization of androgens to estrogens play a key role in estrogenic state. ${ }^{18}$

Failure of usual control mechanisms for apoptotic regulation may be possible causative factors for the promotion of endometrial polyp growth. ${ }^{19}$ An overexpression of $\mathrm{Bcl}-2$ which plays a significant role in regulation of apoptosis was reported in endometrium in the study of McGurgan et al. ${ }^{19}$ These tumors may depend on the intricate balance between proliferation and apoptosis. Based on the proposed etiologies, similar mechanisms may contribute to the development of cervical polyps.

Recently, an extensive study was carried out by Maia et al. This study shows that both endometrial polyps and the normal endometrium undergo changes in the expression of proteins related to proliferation and apoptosis during the menstrual cycle. ${ }^{20}$ Mertens suggested that proliferation is the result of increasing estradiol concentration, high estrogen receptor expression and growth hormones and high Bcl-2 and Ki67 expression. ${ }^{21}$ Bcl-2 levels decrease and Ki67 levels and androgen receptor expression in stromal cells disappear resulting in cell disintegration and menstruation. ${ }^{21}$ In cervical polyps, little is known on the balance between apoptosis, proliferation rates and how ovarian hormones can affect this process. This relationship can provide molecular insight into the development of cervical polyps in obesity.

With advancing age, the incidences of clinical conditions such as DM, HT, and obesity increase and they often coexist, which makes the evaluation of the independent effects of these factors in polyp formation difficult. ${ }^{8}$ The highest percentage of patients with cervical polyp was observed in the 40to 55-year-old age group. Our data are in accordance with the international literature that indicates the age dependent association of cervical polyps.

The highest percentage of patients in these ages may be the additive result of both hormonal effect and advanced age. In premenopausal women, age is more important than BMI as the risk factor for endometrial polyps. ${ }^{22}$ Therefore, in order to reduce the margin of error and to minimize the effect of age, patients with and without cervical polyps were chosen carefully with the same age in our study. Endometrial polyps may be relatively insensitive to cyclic hormonal changes by the facts that they are not encountered prior to menarche, some small polyps spontaneously regress over time and HRT, late menopause and obesity increased the occurrence of endometrial polyps. ${ }^{6,21,23}$ Similarly an abnormal response to certain hormonal stimuli may be involved in the process of cervical polyps. In this study, control group were chosen with the same menopausal status; and cases receiving HRT, birth control pills and Tamoxiphene (Nolvadex, AstraZeneca, UK) were excluded.

$\mathrm{DM}$ is a growing problem in many countries. Although diabetes does not seem to be directly linked to cervical polyps in our study; according to Topcu et al., menopause and DM are strong risk factors for the presence of concomitant endometrial polyps and endometrial hyperplasia. ${ }^{24}$ Published studies focusing on the relationship between DM and polyp are only in endometrial polyps. There are reports of significant correlation between 
$\mathrm{DM}$ and endometrial polyps and there are also reports of no correlation. ${ }^{8,24,25}$ To date few studies have investigated cervical polyps and their pathogenesis in detail.

In this study, we attempted to find out if cervical polyp formation is associated with DM, HT, and obesity. Although HT linked with a large range of medical complications, no correlation was found between cervical polyps and HT. HT may be risk factors for endometrial polyps even if it is not yet clear whether this condition primarily influences the endocervical polyps. ${ }^{8,25}$

This study has some limitations due to its retrospective nature. First, it is a single-center study, thus our findings may not be generalizable to other races or geographic locations. Additionally, this study has been limited by small sample sizes and the lack of disease duration. Since prevalence counts both new and existing cases, the duration of the disease affects the prevalence. The cumulative long-term effects of obesity, DM, and HT may alter the results.

Although DM and HT do not seem to be directly linked to cervical polyps in our study, obesity appears to be a risk factor for cervical polyps in our hospital-based populations. Obese women should receive special attention for potential coexistence of cervical polyps as part of their gynecological evaluation and also this supports the importance of weight management for the preventive plan of cervical polyps. Further prospective randomized controlled trials are needed to verify these findings in large samples.

The English in this document has been checked by a native speaker of English.

\section{REFERENCES}

1. Berzolla CE, Schnatz PF, O'Sullivan DM, Bansal R, Mandavilli S, Sorosky JI. Dysplasia and malignancy in endocervical polyps. J Womens Health (Larchmt) 2007;16(9):131721.

2. Bucella D, Frédéric B, Noël JC. Giant cervical polyp: a case report and review of a rare entity. Arch Gynecol Obstet 2008;278(3): 295-8.

3. Aridogan N, Cetin MT, Kadayifci O, Atay Y, Bisak U. Giant cervical polyp due to a foreign body in a 'virgin'. Aust N Z J Obstet Gynaecol 1998;28(2):146-7.

4. Stamatellos I, Stamatopoulos P, Bontis J. The role of hysteroscopy in the current management of the cervical polyps. Arch Gynecol Obstet 2007;276(4):299-303.

5. Schnatz PF, Ricci S, O'Sullivan DM. Cervical polyps in postmenopausal women: is there a difference in risk? Menopause 2009;16(3): 524-8.

6. Oguz S, Sargin A, Kelekci S, Aytan H, Tapisiz $\mathrm{OL}$, Mollamahmutoglu $\mathrm{L}$. The role of hormone replacement therapy in endometrial polyp formation. Maturitas 2005;50(3):231-6.

7. Reslová T, Tosner J, Resl M, Kugler R, Vávrová I. Endometrial polyps. A clinical study of 245 cases. Arch Gynecol Obstet 1999; 262(3-4):133-9.

8. Serhat E, Cogendez E, Selcuk S, Asoglu MR, Arioglu PF, Eren S. Is there a relationship be- tween endometrial polyps and obesity, diabetes mellitus, hypertension? Arch Gynecol Obstet 2014;290(5):937-41.

9. Vilodre LC, Bertat R, Petters R, Reis FM. Cervical polyp as risk factor for hysteroscopically diagnosed endometrial polyps. Gynecol Obstet Invest 1997;44(3):191-5.

10. Indraccolo U, Barbieri F. Relationship between adenomyosis and uterine polyps. Eur J Obstet Gynecol Reprod Biol 2011;157(2): 185-9.

11. Neri A, Kaplan B, Rabinerson D, Ovadia J, Braslavsky D. Cervical polyp in menopause and the need for fractional dilation and curettage. Eur J Obstet Gynecol Reprod Biol 1995;62(1):53-5.

12. Ozsaran AA, Itil IM, Sağol S. Endometrial hyperplasia co-existing with cervical polyps. Int J Gynaecol Obstet 1999;66(2):1856.

13. Pandey S, Bhattacharya S. Impact of obesity on gynecology. Womens Health (Lond) 2010; 6(1):107-17.

14. Rutanen EM, Pekonen F, Nyman T, Wahlström T. Insulin-like growth factors and their binding proteins in benign and malignant uterine disease. Growth Regul 1993; 3(1):74-7.

15. Inceboz US, Nese N, Uyar $\mathrm{Y}$, Ozcakir HT, Kurtul O, Baytur YB, et al. Hormone receptor expressions and proliferation markers in postmenopausal endometrial polyps. Gynecol Obstet Invest 2006;61(1): 24-8.

16. Maia H, Maltez A, Athayde C, Coutinho EM. Proliferation profile of endometrial polyps in post-menopausal women. Maturitas 2001; 40(3):273-81.

17. Rutanen EM, Stenman $S$, Blum W, Kärkkäinen T, Lehtovirta P, Stenman UH. Relationship between carbohydrate metabolism and serum insulin-like growth factor system in postmenopausal women: comparison of endometrial cancer patients with healthy controls. J Clin Endocrinol Metab 1993;77(1): 199-204.

18. Diamanti-Kandarakis $E$, Bergiele A. The influence of obesity on hyperandrogenism and infertility in the female. Obes Rev 2001;2(4): 231-8.

19. McGurgan P, Taylor LJ, Duffy SR, O'Donovan PJ. Are endometrial polyps from pre-menopausal women similar to post-menopausal women? An immunohistochemical comparison of endometrial polyps from pre- and postmenopausal women. Maturitas 2006;54(3): 277-84.

20. Maia H Jr, Maltez A, Studart E, Athayde C Coutinho EM. Ki-67, Bcl-2 and p53 expression in endometrial polyps and in the normal endometrium during the menstrual cycle. BJOG 2004;111(11):1242-7. 
21. Mertens HJ, Heinemam MJ, Evers JL. The expression of apoptosis-related proteins $\mathrm{Bcl}-2$ and Ki67 in endometrium of ovulatory menstrual cycles. Gynecol Obstet Invest 2002; 53(4):224-30.

22. Lubián López DM, Orihuela López F, GarcíaBerbel Molina L, Boza Novo P, Pozuelo Solís E, Menor Almagro D, et al. Endometrial polyps in obese asymptomatic pre and post- menopausal patients with breast cancer: is screening necessary? Gynecol Oncol 2014; 133(1):56-62.

23. Mittal K, Schwarz L, Goswami S, Demopoulos R. Estrogen and progesterone receptor expression in endometrial polyps. Int J Gynecol Pathol 1996;15(4):345-8.

24. Topcu HO, Erkaya S, Guzel Al, Kokanali MK, Sarikaya E, Muftuoglu KH, et al. Risk factors for endometrial hyperplasia concomitant endometrial polyps in pre- and post-menopausal women. Asian Pac J Cancer Prev 2014; 15(13):5423-5.

25. Nappi L, Indraccolo U, Di Spiezio Sardo A, Gentile G, Palombino K, Castaldi MA, et al. Are diabetes, hypertension, and obesity independent risk factors for endometrial polyps? J Minim Invasive Gynecol 2009;16(2):157-62. 